\title{
Direct and Joint Effects of Genotype, Defoliation and Crop Density on the Yield of Three Inbred Maize Lines
}

\author{
Dejan Ranković $^{1, *}$, Goran Todorović ${ }^{1}$, Marijenka Tabaković ${ }^{1}$ (D) Slaven Prodanović ${ }^{2}$, Jan Boćanski ${ }^{3}$ \\ and Nenad Delić ${ }^{1}$ \\ 1 Maize Research Institute, Zemun Polje, 11185 Belgrade-Zemun, Serbia; gtodorovic@mrizp.rs (G.T.); \\ mtabakovic@mrizp.rs (M.T.); ndelic@mrizp.rs (N.D.) \\ 2 Faculty of Agriculture, University of Belgrade, 11080 Belgrade-Zemun, Serbia; slavenp@agrif.bg.ac.rs \\ 3 Faculty of Agriculture, University of Novi Sad, 21000 Novi Sad, Serbia; bocanski@polj.uns.ac.rs \\ * Correspondence: drankovic@mrizp.rs; Tel.: +381-11-3756-704
}

Citation: Ranković, D.; Todorović, G.; Tabaković, M.; Prodanović, S.; Boćanski, J.; Delić, N. Direct and Joint Effects of Genotype, Defoliation and Crop Density on the Yield of Three Inbred Maize Lines. Agriculture 2021, 11, 509. https://doi.org/10.3390/ agriculture11060509

Academic Editor: Rentao Song

Received: 29 April 2021

Accepted: 28 May 2021

Published: 31 May 2021

Publisher's Note: MDPI stays neutral with regard to jurisdictional claims in published maps and institutional affiliations.

Copyright: (c) 2021 by the authors. Licensee MDPI, Basel, Switzerland. This article is an open access article distributed under the terms and conditions of the Creative Commons Attribution (CC BY) license (https:// creativecommons.org/licenses/by/ $4.0 /)$.

\begin{abstract}
The aim of this study was to observe direct and joint effects of three factors (genotypes, ecological environmental conditions and the applied crop density) on the level of defoliation intensity and yield. Three inbred lines (G) of maize (G1-L217RfC, G2-L335/99 and G3-L76B004) were used in the study. The trials were performed in two years $(\mathrm{Y})(\mathrm{Y} 1=2016$ and $\mathrm{Y} 2=2017)$ and in two locations (L) (L1 and L2) under four ecological conditions of the year-location interaction (E1-E4) and in two densities (D1 and D2) (50,000 and 65,000 plants ha ${ }^{-1}$ ). Prior to tasselling, the following five treatments of detasseling and defoliation (T) were applied: T1—control, no leaf removal only detasseling, T2-T5-removal of tassels and top leaves (from one to four top leaves). The defoliation treatments had the most pronounced effect on the yield reduction in G1 (T1-Tn+1 . . T5), $p<0.05$. The ecological conditions on yield variability were expressed under poor weather conditions (E3 and E4), while lower densities were less favorable for the application of defoliation treatments. The result of joint effects of factors was the lowest grain yield ( $896 \mathrm{~kg} / \mathrm{ha})$ in G3 in the variant E3D1 for T2 and the highest grain yield (11,389 kg/ha) in G3 in the variant E2D2 for T1. The smallest effect of the defoliation treatment was on the kernel row number (KRN).
\end{abstract}

Keywords: maize; detasseling; remove top leafs; location; year; properties

\section{Introduction}

The seed production of inbred lines and $\mathrm{F}_{1}$ hybrids requires the removal of tassels from the female parent. This removal prevents uncontrolled pollination, and then the appropriate genetic background in the seed is provided by self-pollination or by effects of anemophily [1,2] or by any other appropriate crossing. Detasseling is done prior to full maturity of anthers, when the tassel has emerged out of the leaf sheath. Detasseling is approached very carefully, it is performed either manually with a skilled labor $[3,4]$, since the base of the tassel is not visible, or mechanically. With more intensive defoliation, there is greater certainty that the entire tassel would be removed. When knives cutters are adjusted to remove the longer top portion of the plant, the variation in the stalk height does not affect the success of detasseling. Regardless of manual or mechanical detasseling, more intensive defoliation reduces the cost of control of the presence of tassel residues on plants in the seed crop. However, more intensive defoliation can cause a decrease in the grain yield [5-8]. The loss in the grain yield results in the lower income from the seed production, which can nullify the savings achieved by the decreased defoliation intensity.

The intensity of defoliation in which there is no significant reduction in yield or the occurrence of other side effects in inbred lines and their seeds can be designated as "safe" ("harmless") treatment (level) of defoliation. The terms "optimum leaf defoliation" and "judicious defoliation" of maize plants have been used by Raza et al. [9]. These terms are related to treatments that improve the nutrient uptake and do not reduce yield. Slower 
seed maturation can be one of the undesirable effects of defoliation. Modarres et al. [10] stated that leafy-reduced maize inbred lines have a higher grain moisture content at harvest than leafy inbreds.

Seed producers are interested in the increase of the intensity of defoliation, but only up to a safe level. Effects of defoliation and the safe level of defoliation vary depending on different factors, such as: genotype, environmental conditions, crop density, mode, timing and intensity of defoliation. The results obtained in several studies dealing with the effects of various factors on defoliation have been published [11-15].

In one of the initial studies within this field [16], the response of six maize (Zea mays L.) inbreds was evaluated to $50 \%$ and $100 \%$ defoliation at the 14-leaf stage regarding grain yields and yield components. Frascaroli et al. [17] studied the response of six inbred lines of maize (B73, IABO78, Lo1016, Lo964, Mo17 and Os420) to different defoliation treatments in three environments. Raza et al. [9] investigated the effects of four-leaf excision treatments $\left(\mathrm{T}_{1}-0 ; \mathrm{T}_{2}-2 ; \mathrm{T}_{3}-4\right.$ and $\mathrm{T}_{4}-6$ leaves excised from the top of maize plants) on grain yield of maize through two-year field experiments. Shekoofa et al. [18] analyzed changes in yields and yield components when all the leaves were removed from one side of the maize plants in three hybrids in three plant densities.

The aim of this study was to establish the direct and combined joint effects of three factors: genotypes (inbred lines), environment and applied cropping practices (crop density) on the safe level of defoliation, including quadruple interactions. These studies are important for the management of seed production and improvement detasseling and defoliation technology to prevent yield losses.

\section{Materials and Methods}

\subsection{Plant Material and Field Experiment}

Three maize inbred lines (G), designated as G1-L217RfC, G2-L335/99 and G3-L76B004, were used in the study. Each inbred was derived at the Maize Research Institute, Zemun Polje, Serbia. These inbreds are parental components of commercial hybrids. G1 is a female component of the hybrids ZP 341, ZP 434 and ZP 360. G2 is a female component of the hybrids ZP 555, ZP 606 and ZP 666, while G3 is a female component of the hybrids ZP 560 and ZP 600. These inbreds belong to the following heterotic groups: BSSS $(\mathrm{G} 2, \mathrm{G} 3)$ and Iowa Dent (G1).

The three-replicate trail was set up according to the randomized complete block design (RCBD) in 2016. The distance between replicates amounted to $1 \mathrm{~m}$. The elementary plot included three $5-\mathrm{m}$ rows of plants with the inter-row distance of $70 \mathrm{~cm}$. The size of the elementary plot was $0.35 \mathrm{~m}^{2}$.

The studies were performed during two years $(Y 1=2016$ and $Y 2=2017)$ in two loca-

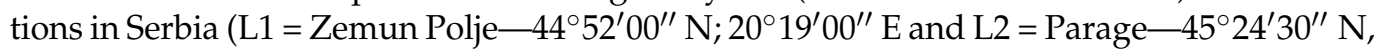
$\left.19^{\circ} 24^{\prime} 07^{\prime \prime} \mathrm{E}\right)$. The soil in L1 was degraded chernozem of the second class, while the soil in L2 was calcareous chernozem of the first class. Soil analyses were performed by standard methods for determining quality: soil $\mathrm{pH}$ in $\mathrm{KCl}$ was determined in a 1:2.5soil-1 $\mathrm{MKCl}$ suspension after a half-hour equilibration period; $\mathrm{CaCO}_{3}$ was determined by the method Scheibler with a calcimeter; organic matter content was determined by Kotzmann's method; the Kjeldahl method was used to determine total N, while the content of available phosphorus $\left(\mathrm{P}_{2} \mathrm{O}_{5}\right)$ and potassium $\left(\mathrm{K}_{2} \mathrm{O}\right)$ was established by the standard AL-method according to Egner-Riehm (Table 1).

The trial was set up under rainfed conditions, so that the differences in ecological conditions between years and locations would be as pronounced as possible. In such a way, data were obtained for four year-location interactions: E1 (Y1L1), E2 (Y1L2), E3 (Y2L1) and E4 (Y2L2). Inbred lines were tested in two densities (D): D1 = 50,000 plants ha ${ }^{-1}$ and $\mathrm{D} 2=65,000$ plants $\mathrm{ha}^{-1}$. Sowing was done in mid-April. The plant distance within the row was adjusted to 28.57 and $21.98 \mathrm{~cm}$ in D1 and D2, respectively.

Standard cropping practices for maize were applied. Prior to tasseling, the following five treatments of detasseling and defoliation (T) were applied: T1—control, no leaf 
removal, only detasseling, T2 - removal of tassel and one top leaf, T3-removal of tassel and two top leaves, T4-removal of tassel and three top leaves, T5-removal of tassel and four top leaves (Table 2).

Table 1. Soil properties.

\begin{tabular}{|c|c|c|c|c|c|c|c|c|}
\hline & \multirow{2}{*}{$\begin{array}{l}\text { Soil Layer } \\
\text { (cm) }\end{array}$} & \multicolumn{2}{|c|}{$\mathrm{pH}$} & \multirow{2}{*}{$\begin{array}{c}\mathrm{CaCO}_{3} \\
(\%)\end{array}$} & \multirow{2}{*}{ OM (\%) } & \multirow{2}{*}{$\begin{array}{c}\text { total N } \\
(\%)\end{array}$} & \multirow{2}{*}{$\begin{array}{c}\mathrm{P}_{2} \mathrm{O}_{5} \\
\mathrm{mg} / 100 \mathrm{~g}\end{array}$} & \multirow{2}{*}{$\begin{array}{c}\mathrm{K}_{2} \mathrm{O} \\
\mathrm{mg} / 100 \mathrm{~g}\end{array}$} \\
\hline & & KCL & $\mathrm{H}_{2} \mathrm{O}$ & & & & & \\
\hline L1Y1 & $0-30$ & 7.10 & 8.10 & 1.20 & 2.70 & 0.19 & 39.20 & 20.80 \\
\hline L1Y2 & $0-30$ & 7.30 & 8.40 & 3.30 & 2.60 & 0.19 & 25.90 & 25.70 \\
\hline L2Y1 & $0-30$ & 7.61 & 8.16 & 5.58 & 2.53 & 0.13 & 18.66 & 24.85 \\
\hline L2Y2 & $0-30$ & 7.64 & 8.22 & 7.42 & 2.77 & 0.13 & 28.17 & 24.85 \\
\hline
\end{tabular}

L1Y1-Zemun Polje/2016; L1Y2-Zemun Polje/2017; L2Y1-Parage/2016; L2Y2-Parage/2017.

Table 2. Treatment of detasseling and defoliation (T).

\begin{tabular}{cc}
\hline Treatment & Removal of (Tassel + Top Leaf) \\
\hline T1 & $\mathrm{T}$ \\
T2 & $\mathrm{T}+1 \mathrm{TL}$ \\
T3 & $\mathrm{T}+2 \mathrm{TL}$ \\
T4 & $\mathrm{T}+3 \mathrm{TL}$ \\
T5 & $\mathrm{T}+4 \mathrm{TL}$ \\
\hline
\end{tabular}

T-Tassel, TL-Top leaf.

The removal of tassels and leaves was done by hand. All ears from the middle row were used to measure the yield. Ears were harvested manually at the stage of full grain maturity, whereby the grain yield was measured and the moisture content was determined for each sample. Then, the grain yield of all variants in the trial was calculated to $14 \%$ moisture. The moisture content was determined using a hygrometer (Perten instruments AB, AM 5200-A, Sweden).

The sample of five ears of each variant $(3(\mathrm{G}) \times 2(\mathrm{Y}) \times 2(\mathrm{~L}) \times 2(\mathrm{D}) \times 5(\mathrm{~T})=120)$ was drawn to determine the kernel row number (KRN), kernel number per row (KNR), the ear length (EL), and kernel weight. The kernel row number (KRN) was measured by counting the rows of kernels of each ear from the sample (five ears), KNR was established by counting three rows of kernels from each ear from the sample, EL was determined by measuring the length of five ears from each sample with a ruler $(0-1000 \mathrm{~mm})$, and the kernel weight $(\mathrm{KW})$ was established by counting $10 \times 100$ kernels and then by measuring on the digital balance (Tehtnica ET 1111, max-1200.00/120.00 g, e-0.1 g, dd-0.1/0.01 g, Serbia).

\subsection{Precipitation and Temperature Data}

The average temperature was lower in $\mathrm{Y} 1$ than in $\mathrm{Y} 2$ in both locations (by $0.8^{\circ} \mathrm{C}$ $\left(19.40-20.2{ }^{\circ} \mathrm{C}\right)$ in L1 = Zemun Polje, and by $0.7^{\circ} \mathrm{C}\left(18.1-18.8^{\circ} \mathrm{C}\right)$ in L2-Parage). Y1 was characterized by a higher amount of precipitation during the growing season of maize (April-October) than Y2.

\subsection{Statistical Analysis of Data}

The statistical analysis encompassed 360 data on the value of grain yield ( 3 genotypes $\times 4$ year-location interactions $\times 2$ crop densities $\times 5$ defoliation treatments $\times 3$ replications), kernel row number, kernel number per row, 1000-kernel weight, and germination. The analysis of variance (ANOVA), type III sum of squares, was applied to estimate the significance of main factors (G, E, D and T) and their interactions. The descriptive statistics was used to describe basic features, including the mean, standard deviation, minimum, maximum and the range of variants, within each factor. Factors, for which the significance of differences between their variants in ANOVA were determined, were analyzed separately. First, the data file was split into appropriate groups, and then the univariate analysis, 
with the grain yield as a dependent variable, was applied. Post hoc multiple comparisons were done by the LSD test, for the significance level 0.05 and 0.01 [19]. Statistical analyses were performed using the SPSS version 20 (IBM, Armonk, NY, USA).

\section{Results}

3.1. Effect of Genotype, Year, Location and Density on Grain Yield and Yield Components under Different Detasseling Treatments

ANOVA showed that there were statistically significant differences among variants $G$, $\mathrm{E}$ and $\mathrm{D}$, as well as among treatments of defoliation (T) (Table 3). This points out that the grain yield, morphological traits or yield components (KRN, KNR, EL, KW) significantly depended on the intensity of defoliation, as well as on effects of defoliation that were observed in this study [20]. The statistical significance obtained by the analysis of variance justifies the choice of factorial variants and provides the meaning of the factorial analysis.

Table 3. Estimation of factor contribution to grain yield, kernel rows number, kernel number per rows, ear length, 1000-kernel weight (ANOVA).

\begin{tabular}{|c|c|c|c|c|c|}
\hline Source & ${ }^{a} \mathrm{GY}$ & ${ }^{b}$ KRN & ${ }^{\mathrm{c}} \mathrm{KNR}$ & ${ }^{\mathrm{d}}$ EL & e $\mathbf{K W}$ \\
\hline G & $59.563^{* * *}$ & $195.323^{* * *}$ & $140.873^{* * *}$ & $10.932^{* * *}$ & $182.668^{* * *}$ \\
\hline $\mathrm{E}$ & $2495.874^{* * *}$ & $525.427^{* * *}$ & $1311.885^{* * *}$ & $1103.954^{* * *}$ & $168.828^{* * *}$ \\
\hline $\mathrm{D}$ & 5.146 * & $12.193^{* *}$ & $37.046^{* * *}$ & $75.143^{* * *}$ & $24.831^{* * *}$ \\
\hline $\mathrm{T}$ & $36.308 * * *$ & $0.285 \mathrm{~ns}$ & $52.773 * * *$ & $17.891^{* * *}$ & $676.697 * *$ \\
\hline $\mathrm{G} \times \mathrm{E}$ & $121.272 * * *$ & $90.942^{* * *}$ & $54.693 * * *$ & $56.748^{* * *}$ & $52.095 * * *$ \\
\hline$G \times D$ & $5.574^{* *}$ & $4.085^{*}$ & $3.506 *$ & $4.919 * *$ & $5.215^{* *}$ \\
\hline $\mathrm{G} \times \mathrm{T}$ & $1.596 \mathrm{~ns}$ & $3.152 * *$ & $1.844 \mathrm{~ns}$ & $0.636 \mathrm{~ns}$ & $3.307^{* *}$ \\
\hline $\mathrm{E} \times \mathrm{D}$ & $4.552 * *$ & $6.192 * * *$ & $1.189 \mathrm{~ns}$ & $7.234 * * *$ & $2.203 \mathrm{~ns}$ \\
\hline $\mathrm{E} \times \mathrm{T}$ & $8.528 * * *$ & $0.883 \mathrm{~ns}$ & $6.078^{* * *}$ & $5.160 * * *$ & $1.592 \mathrm{~ns}$ \\
\hline $\mathrm{D} \times \mathrm{T}$ & $0.789 \mathrm{~ns}$ & $4.268 * *$ & $1.731 \mathrm{~ns}$ & $1.918 \mathrm{~ns}$ & $1.495 \mathrm{~ns}$ \\
\hline$G \times E \times D$ & $1.671 \mathrm{~ns}$ & $2.344 *$ & $0.632 \mathrm{~ns}$ & $4.874^{* * *}$ & $1.588 \mathrm{~ns}$ \\
\hline $\mathrm{G} \times \mathrm{E} \times \mathrm{T}$ & $2.681^{* * *}$ & $0.832 \mathrm{~ns}$ & $2.599^{* * *}$ & $2.869^{* * *}$ & $1.271 \mathrm{~ns}$ \\
\hline $\mathrm{G} \times \mathrm{D} \times \mathrm{T}$ & $2.363 *$ & $3.269 * *$ & $2.228 *$ & $0.882 \mathrm{~ns}$ & $0.490 \mathrm{~ns}$ \\
\hline $\mathrm{E} \times \mathrm{D} \times \mathrm{T}$ & $3.154 * *$ & $2.108 *$ & $1.877^{*}$ & $1.262 \mathrm{~ns}$ & $2.061 *$ \\
\hline $\mathrm{G} \times \mathrm{E} \times \mathrm{D} \times \mathrm{T}$ & $1.653 *$ & 1.940 * & $1.291 \mathrm{~ns}$ & $1.919 * *$ & $1.583 *$ \\
\hline Error & $69,510,756.000$ & 240 & $289,628.150$ & & \\
\hline Total & $12,261,433,404.000$ & 360 & & & \\
\hline Corrected Total & $2,617,841,433.156$ & 359 & & & \\
\hline
\end{tabular}

a R Squared $=0.973$ (Adjusted R Squared $=0.960) ;{ }^{b}$ R Squared $=0.919$ (Adjusted R Squared $=0.880$ )

c $R$ Squared $=0.953$ (Adjusted R Squared $=0.930)$, ${ }^{\mathrm{d}} \mathrm{R}$ Squared $=0.946$ (Adjusted R Squared $=0.919$ );

e R Squared $=0.854$ (Adjusted R Squared $=0.781$ ); KRN—-kernel row number; KNR-kernel number per row; EL-ear length; KW-1000-kernel weight; * The mean difference is significant at the 0.05 level, ${ }^{* *}$ The mean difference is significant at the 0.01 level, ${ }^{* * *}$ The mean difference is significant at the 0.001 level, ns—not significant.

High yields in the production of various crops are achieved by the selection of genotypes with the greatest possible yield potential. The statistical significance of the $G \times T$ interaction in ANOVA indicates that the most yielding inbred lines did not have the highest grain yield in all treatments of defoliation.

The favorable production conditions (location, types of soil) and the application of appropriate cropping practices are a prerequisite for achieving high grain yields [21]. However, based on the statistical significance of double interactions $\mathrm{E} \times \mathrm{T}$ and $\mathrm{D} \times \mathrm{T}$ in ANOVA, it is observed that the most favorable year-location interactions and cropping practices did not always mean the highest grain yields in all defoliation treatments.

The statistical significance of triple interactions $\mathrm{G} \times \mathrm{D} \times \mathrm{T}$ and $\mathrm{E} \times \mathrm{D} \times \mathrm{T}$ in ANOVA, as well as the statistical significance of quadruple $\mathrm{G} \times \mathrm{E} \times \mathrm{D} \times \mathrm{T}$ interaction in ANOVA, indicate that, in addition to the direct effects of individual factors on grain yields in various defoliation treatments, their combined effects also played a significant role.

The ANOVA results suggest that it is possible to reduce grain yield losses during defoliation by applying individual variants and by combining variants $G, E$ and $D$. At the same time, the determination of an individual factor and a combination of factors that 
provide a significant reduction in yield losses during defoliation is very important for seed producers.

In plant breeding, the type of a relationship among yield components is important in order to develop genotypes with high genetic potential [22].

Grain yield can be equal with different contributions of individual yield components $[23,24]$. The importance of all individual factors on KNR, EL and KW was determined by the analysis of variance of morphological seed traits [25-27]. The trait KRN stood out, as defoliation treatments had no significant effects on the variation of mean values in this study.

The interaction of factors was also present in the variation of morphological traits. Double, triple and quadruple interactions with the factor $\mathrm{T}$ did not show statistical significance. The double interactions $\mathrm{G} \times \mathrm{T}$ and $\mathrm{D} \times \mathrm{T}$ had the least impact on the formation of KNR, El and KW. This points to the fact that attention should be paid to the selection of seed material and cropping practices in the process of crop sowing, due to the large variable possibilities of factor actions (Table 1 ).

\subsection{Seed Yield in Trial Variants}

The lowest seed grain $(896 \mathrm{~kg} / \mathrm{ha})$ in the trial was detected in G3 in the variant E3D1 for T2, while the highest one $(11,389 \mathrm{~kg} / \mathrm{ha})$ was recorded in the same genotype in the variant E2D2 for T1 (Table 4). This result indicates a low stability of G3 seed yields in various variants and treatments, but also the possibility to remove relatively small leaf mass, which can lead to a significant reduction in yield. According to data, G3 responded with a large reduction in grain yield in the adverse unfavorable year of 2017 compared to the genotypes G1 and G2. The reason for this may be that G3 has a longer growing season that the remaining two inbred lines, thus grain filling in this inbred under conditions of drought in 2017 ceased earlier than in G1 and G2. The first year of investigation $(Y 1=2016)$ was more favorable for maize production than the second one $(Y 2=2017)$ (Figure 1). whereby in both years, maize had more available moisture for the growth and development in L2 than in L1. Thus, in Y1, the precipitation sum in L1 and L2 amounted to 498 and $537 \mathrm{~mm}$, respectively, while the corresponding sums for $\mathrm{Y} 2$ were 349 and $356 \mathrm{~mm}$. The range (max-min) of all variants tested in the trial amounted to $10.493 \mathrm{~kg} / \mathrm{ha}$. The average yield of all trial variants was $5175.684 \mathrm{~kg} / \mathrm{ha}$, with a standard deviation of $2671.737 \mathrm{~kg} / \mathrm{ha}$ and a coefficient of variation of $51.62 \%$.
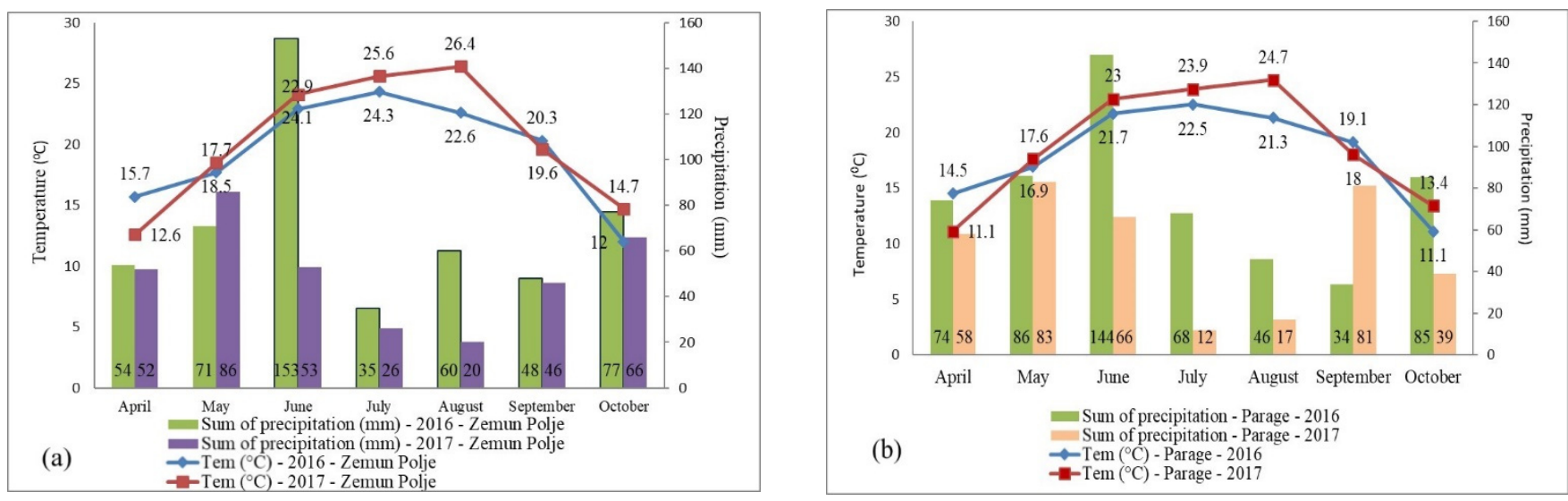

Figure 1. (a) Temperature and precipitation data in 2016 (Y1) and 2017 (Y2) in the location of Zemun Polje (L1); (b) Temperature and precipitation data in 2016 (Y1) and 2017 (Y2) in location of Parage (L2).

\subsection{Descriptive Statistics and Mean Differences of Studied Factors and Defoliation Treatments}

According to values obtained for $\mathrm{G}$ (Table 5), the highest, i.e., lowest grain yield (5549.4 and $4791.3 \mathrm{~kg} /$ ha, respectively) were recorded in G2 and G3, respectively. Differences among average yields of all genotypes were very significant (Table 6). 
Table 4. Average yield ( $\mathrm{kg} / \mathrm{ha}$ ) of three maize inbreed lines grown in four year-location interactions in two densities for five defoliation treatments.

\begin{tabular}{|c|c|c|c|c|c|c|c|}
\hline \multirow{2}{*}{ G } & \multirow{2}{*}{$\mathbf{E}$} & \multirow{2}{*}{ D } & \multicolumn{5}{|c|}{$\mathbf{T}$} \\
\hline & & & T1 & T2 & T3 & $\mathrm{T} 4$ & T5 \\
\hline \multirow{9}{*}{ G1 } & \multirow{2}{*}{ E1 } & D1 & 6487 & 5848 & 5587 & 5717 & 5145 \\
\hline & & D2 & 6468 & 6836 & 6158 & 6863 & 5840 \\
\hline & \multirow{2}{*}{ E2 } & D1 & 7149 & 7776 & 7035 & 6829 & 5777 \\
\hline & & D2 & 8579 & 8455 & 8196 & 7216 & 6132 \\
\hline & \multirow{2}{*}{ E3 } & D1 & 3614 & 3876 & 3735 & 4069 & 3092 \\
\hline & & D2 & 3559 & 4292 & 3758 & 3732 & 2967 \\
\hline & \multirow{2}{*}{ E4 } & D1 & 4444 & 3196 & 3686 & 3525 & 3473 \\
\hline & & D2 & 4460 & 3445 & 3522 & 3239 & 3673 \\
\hline & \multirow{2}{*}{ E1 } & D1 & 7463 & 7312 & 7619 & 7483 & 6096 \\
\hline \multirow{7}{*}{ G2 } & & D2 & 7089 & 6519 & 6855 & 7656 & 6158 \\
\hline & \multirow[b]{2}{*}{ E2 } & D1 & 9670 & 8537 & 9064 & 8789 & 7997 \\
\hline & & D2 & 9566 & 9839 & 10,000 & 8311 & 7297 \\
\hline & \multirow[b]{2}{*}{ E3 } & D1 & 4022 & 3808 & 4305 & 2899 & 3233 \\
\hline & & D2 & 3531 & 3676 & 3238 & 4027 & 2866 \\
\hline & & D1 & 2795 & 3452 & 2546 & 2284 & 2582 \\
\hline & E4 & D2 & 2050 & 2259 & 2810 & 3826 & 2444 \\
\hline \multirow{8}{*}{ G3 } & \multirow{2}{*}{ E1 } & D1 & 6464 & 6125 & 6660 & 6537 & 5561 \\
\hline & & D2 & 6612 & 6161 & 6383 & 5203 & 6220 \\
\hline & \multirow{2}{*}{ E2 } & D1 & 10,338 & 9320 & 9464 & 9005 & 8329 \\
\hline & & D2 & 11,389 & 9704 & 10,812 & 9215 & 7668 \\
\hline & \multirow{2}{*}{ E3 } & D1 & 1154 & 896 & 1236 & 1145 & 1074 \\
\hline & & D2 & 1067 & 1055 & 1729 & 1147 & 958 \\
\hline & \multirow{2}{*}{$\mathrm{E} 4$} & D1 & 1547 & 3038 & 2316 & 2329 & 2125 \\
\hline & & D2 & 1852 & 2338 & 2800 & 2808 & 1870 \\
\hline $\begin{array}{l}\text { G: Genot } \\
\text { Polje 2017 } \\
\text { (T1-con } \\
\text { detasselir }\end{array}$ & $D^{-1}$ & & interac & $-\mathrm{Ze}$ & je 2016 & arage & $\begin{array}{l}3-\mathrm{Ze} \\
\text { defoli }\end{array}$ \\
\hline
\end{tabular}

Table 5. Descriptive statistics for the genotype, the year-location interaction, crop density and the defoliation treatment.

\begin{tabular}{cccccccc}
\hline \multirow{2}{*}{ Factor } & Variant & $\mathbf{N}$ & \multicolumn{5}{c}{ Yield (kg/ha) } \\
\cline { 4 - 8 } & & & Mean & $\mathbf{S}^{\mathbf{2}}$ & Minimum & Maximum & Range \\
\hline \multirow{4}{*}{ G } & G1 & 120 & 5186.3 & $2,941,798.427$ & 2446 & 8676 & 6230 \\
& G2 & 120 & 5549.4 & $7,036,759.979$ & 1672 & 10,806 & 9134 \\
& G3 & 120 & 4791.3 & $11,730,172.849$ & 189 & 11,794 & 11,605 \\
& E1 & 90 & 6437.6 & $697,323.256$ & 4832 & 8656 & 3824 \\
E & E2 & 90 & 8582.0 & $1,946,069.211$ & 5049 & 11,794 & 6745 \\
& E3 & 90 & 2792.0 & $1,683,089.706$ & 189 & 5720 & 5531 \\
& E4 & 90 & 2891.2 & $720,879.826$ & 1272 & 4791 & 3519 \\
D & D1 & 180 & 5111.3 & $6,802,029.6465$ & 189 & 11,648 & 11,459 \\
& D2 & 180 & 5240.0 & $7,814,456.155$ & 645 & 11,794 & 11,149 \\
& T1 & 72 & 5473.7 & $9,284,806.394$ & 772 & 11,794 & 11,022 \\
& T2 & 72 & 5323.6 & $7,478,895.490$ & 189 & 10,806 & 10,617 \\
T & T3 & 72 & 5396.4 & $7,911,992.660$ & 1041 & 11,090 & 10,049 \\
& T4 & 72 & 5160.7 & $6,579,607.793$ & 645 & 9883 & 9238 \\
& T5 & 72 & 4524.1 & $5,023,261.711$ & 811 & 8947 & 8136 \\
\hline
\end{tabular}

G: Genotype (G1-, G2-, G3-), E: Year-location interaction (E1-Zemun Polje 2016, E2—Parage 2016, E3-Zemun Polje 2017, E4-Parage 2017), D: Density (D1-50.000 plants ha ${ }^{-1}$, D2-65,000 plants ha ${ }^{-1}$ ), T: Treatment of defoliation (T1-control, detasseling, T2 - detasseling + 1 leaf, T3-detasseling + 2 leaves, T4-detasseling + 3 leaves, $\mathrm{T} 5$ - detasseling +4 leaves); $\mathrm{N}$-samples size; $\mathrm{S}^{2}$ —variance.

It is interesting that the most yielding genotype was characterized by higher yield stability than the least yielding genotype, based on values of their standard deviations. The lowest standard deviation and the smallest range of variation were detected in G2. 
Table 6. Differences in mean yield ( $\mathrm{kg} / \mathrm{ha})$ of genotypes.

\begin{tabular}{ccccc}
\hline Gn & Gm & Gn-Gm & Sig. & Standard Error \\
\hline G1 & G2 & $-363^{* *}$ & 0.000 & \\
G2 & G3 & $394^{* *}$ & 0.000 & 69.488 \\
\hline
\end{tabular}

G: Genotype (G1-, G2-, G3-), Gn—first column of factor G; Gm—second column of factor G; Gn-Gmdifferences between the mean values of the factors; ${ }^{* *}$ LSD significant at the 0.01 level.

Based on the E values (Table 5), the highest $(8582 \mathrm{~kg} / \mathrm{ha})$, i.e., lowest $(2792 \mathrm{~kg} / \mathrm{ha})$ grain yield was recorded in E2, i.e., E3, respectively. There was a significant difference among all year-location interactions, except between E3 and E4 (Table 7).

Table 7. Differences in mean yield (kg/ha) over the year-location interactions.

\begin{tabular}{ccccc}
\hline En & Em & En-Em & Sig. & Standard Error \\
\hline & E2 & $-2144^{* *}$ & 0.000 & \\
E1 & E3 & $3645^{* *}$ & 0.000 & \\
& E4 & $3546^{* *}$ & 0.000 & 80.226 \\
E2 & E3 & $5789^{* *}$ & 0.000 & \\
E3 & E4 & $5690^{* *}$ & 0.000 & \\
\hline
\end{tabular}

E: Year-location interaction (E1-Zemun Polje 2016, E2-Parage 2016, E3-Zemun Polje 2017, E4-Parage 2017) En-first column of factor E; Em—second column of factor E; En-Em—differences between the mean values of the factors; ** LSD significant at the 0.01 level.

This result points out that producers of hybrid maize seeds can expect a significant variation in yields under rainfed conditions [28-31]. Significantly lower yields obtained in E3 and E4 than in E1 and E2 are a consequence of unfavorable weather conditions for maize production in 2017 than in 2016. The second production year lacked sufficient amounts of precipitation for obtaining higher yields. The sum of precipitation from April to October amounted to 349 and $356 \mathrm{~mm}$ in E3 and E4, respectively. The significant differences between E1 and E2 suggest that very different yield can be achieved in different locations during the same year. One of the interesting results is that the smallest yield deviation $(835.06 \mathrm{~kg} / \mathrm{ha})$ was recorded under conditions of E1, in which the second highest yield $(6437.6 \mathrm{~kg} / \mathrm{ha})$ was obtained. This leads to a conclusion that the certain year-location interactions contribute to the establishment of yield stability over all observed factors, i.e., they reduce their effects, in conjunction with management systems and plant populations [32-35].

Based on D values (Table 3), the higher yield $(5240.0 \mathrm{~kg} / \mathrm{ha}$ ) was obtained with the higher density (D2) and vice versa the lower density (D1) with the lower yield $(5111.3 \mathrm{~kg} / \mathrm{ha})$. The crop density affects the habitat and the assimilation surface of individual plants. A high sowing density shades the crop canopy, reduces the light transmittance within a population and accelerates leaf senescence, all of which affect photosynthesis of maize and both the accumulation and the distribution of substances and limit the grain development [36-38]. Considering the above stated, it should not be forgotten that the $\mathrm{D} \times \mathrm{E}$ interaction was significant. The range of variation in both sowing densities was equal $(11,459 \mathrm{~kg} / \mathrm{ha})$. The obtained results on D (Table 3) indicate that in order to obtain higher yields in the seed production of maize inbred lines, the denser sowing should be preformed.

Concerning the $\mathrm{T}$ variants, the highest average yield $(5473.7 \mathrm{~kg} / \mathrm{ha})$ was achieved in the variant T1, and the lowest (4524.1 kg/ha) in the variant T5 (Table 3). Pereira [39] considered that the reduction in the assimilation leaf area during defoliation was the main cause of the yield reduction. Compared to the control (T1), significantly lower yields were obtained in T4 and T5 (Table 8). 
Table 8. Differences in mean yield ( $\mathrm{kg} / \mathrm{ha})$ for defoliation treatments.

\begin{tabular}{ccccc}
\hline Tn & Tm & Tn-Tm & Sig. & Standard Error \\
\hline & T2 & 150 & 0.095 & \\
T1 & T3 & 77 & 0.389 & \\
& T4 & $313^{* *}$ & 0.001 & \\
& T5 & $950^{* *}$ & 0.000 & \\
T2 & T3 & -72 & 0.418 & \\
& T4 & 162 & 0.071 & \\
T3 & T5 & $799^{* *}$ & 0.000 & \\
T4 & T4 & $235^{* *}$ & 0.009 & \\
\hline
\end{tabular}

T: Treatment of defoliation (T1-control, detasseling, T2-detasseling + 1 leaf, T3-detasseling + 2 leaves, T4detasseling + 3 leaves, T5-detasseling + 4 leaves); Tn-first column of factor T; Tm-second column of factor T; $\mathrm{Tn}-\mathrm{Tm}$ - differences between the mean values of the factors; ${ }^{* *}$ LSD Significant at the 0.01 level.

The largest reduction in the assimilation leaf area was in the variant $\mathrm{T} 5$, in which four leaves were removed, hence it is logical that the lowest grain yield was obtained in the defoliation treatment. Allometry is clearly observed with the frequency as a response of plants to the compensation attributed to variations in plant populations [40]. Vasilas and Seif [16] estimated that $50 \%$ defoliation at the 14-leaf stage reduced grain yields of maize inbreds by $2.5-17.0 \%$. In this study, mean values of grain yields in T2 and T3 were similar and did not differ significantly from the control treatment, so it can be concluded that the removal of one or two leaves represented the safe intensity of defoliation. This statement is in agreement with the conclusion drawn by Raza et al. [9] that excision of two leaves from the top of maize plants significantly improved the light interception to lower strata leaves and accelerated the biomass partitioning to maize kernels. The standard deviation of the grain yield in this study decreased with the increased defoliation intensity.

\subsection{Joint Effects of Studied Factors on the Yield Loss in Different Defoliation Treatments}

In regard to the seed production of maize inbred lines, it is important to know the effects of individual factors on grain yields and yield losses in different defoliation treatments (Table S1). Nevertheless, it should be borne in mind that factors are not expressed each for itself, but they are inter-related, which is in accordance with the conclusions made by other authors [41,42].

According to all individual genotype $\times$ year-location interaction (Table 9), G3 in E1, as well as G2 and G3 in E3, did not have a significant loss of grain yield in any defoliation treatment.

On the contrary, G1 in E4 had a significant yield loss in all defoliation treatments. It is noticeable that the levels of safe defoliation in the same year-location interaction varied over observed genotypes, but also these levels for the same genotype differed in dependence on $\mathrm{E}$. This suggests that seed producers have the ability to reduce yield losses by producing inbred lines in a particular year-location interaction in the defoliation variant. At the same time, it is important that these conditions provide achieving high yields of the inbred line (Tables S2 and S3).

The last analysis in this study refers to the dissection of the quadruple $\mathrm{G} \times \mathrm{E} \times \mathrm{D} \times \mathrm{T}$ interaction. It was observed that there was a wide range of joint effects of $G, E$ and $D$ on grain yield losses in different defoliation treatments (Table 10).

Effects observed for individual factors can be greatly altered in quadruple interactions. For example, although a higher crop density D2 was found to reduce losses due to defoliation, by observing actual values of yield losses due to defoliation over locations, quite the opposite effect or the neutral effect of crop density, can be observed (Table S4). For instance, yield losses of G1 in E2 are greater in D2 than in D1, in absolute values and significance. 
Table 9. Joint effect of genotype $\times$ year-location interaction on yield losses $(\mathrm{kg} / \mathrm{ha})$ in different defoliation treatments.

\begin{tabular}{cccccc}
\hline \multirow{2}{*}{ G } & Tm & \multicolumn{5}{c}{ T1-Tm } \\
\cline { 3 - 6 } & & E1 & E2 & E3 & E4 \\
\hline \multirow{3}{*}{ G1 } & T2 & 135 & -252 & $-497^{* *}$ & $1132^{* *}$ \\
& T3 & $605^{* *}$ & 248 & -160 & $848^{* *}$ \\
& T4 & 187 & $841^{* *}$ & -314 & $1070^{* *}$ \\
& T5 & $985^{* *}$ & $1909^{* *}$ & $557^{* *}$ & $879^{* *}$ \\
G2 & T2 & 361 & 430 & 35 & -433 \\
& T3 & 40 & 86 & 5 & -256 \\
& T4 & -294 & $1068^{* *}$ & 314 & $-633^{*}$ \\
& T5 & $1149^{* *}$ & $1971^{* *}$ & 727 & -90 \\
G3 & T2 & 394 & $1352^{* *}$ & 135 & $-988^{* *}$ \\
& T3 & $16^{*}$ & 726 & -372 & $-859^{*}$ \\
& T4 & 668 & $1754^{* *}$ & -36 & $-869^{*}$ \\
& T5 & 647 & $2865^{* *}$ & 95 & -298
\end{tabular}

G: Genotype (G1-, G2-, G3-), E: Year-location interaction (E1-Zemun Polje 2016, E2-Parage 2016, E3-Zemun Polje 2017, E4-Parage 2017); T: Treatment of defoliation (T1-control, detasseling, T2-detasseling + 1 leaf, T3-detasseling + 2 leaves, T4-detasseling +3 leaves, T5-detasseling +4 leaves); Tm-column of factor T2, T3, T4, T5; T1-Tm-differences between the mean values of the factors.* The mean difference is significant at the 0.05 level, ** The mean difference is significant at the 0.01 level.

Table 10. Joint effect of genotype, year-location interaction and crop density on yield losses ( $\mathrm{kg} / \mathrm{ha})$ in different defoliation treatments.

\begin{tabular}{|c|c|c|c|c|c|c|c|}
\hline \multirow{3}{*}{$\mathbf{E}$} & \multirow{3}{*}{$\operatorname{Tm}$} & \multicolumn{6}{|c|}{ T1-Tm } \\
\hline & & \multicolumn{2}{|c|}{ G1 } & \multicolumn{2}{|c|}{ G2 } & \multicolumn{2}{|c|}{ G3 } \\
\hline & & D1 & D2 & D1 & D2 & D1 & D2 \\
\hline \multirow{4}{*}{ E1 } & $\mathrm{T} 2$ & $639 *$ & -368 & 151 & 570 & 338 & 450 \\
\hline & T3 & $900 * *$ & 310 & -155 & 235 & -196 & 228 \\
\hline & $\mathrm{T} 4$ & $770 * *$ & -395 & -20 & -567 & -73 & 1409 \\
\hline & T5 & 1342 ** & $627 *$ & $1367^{* *}$ & 931 & 902 & 391 \\
\hline \multirow{4}{*}{ E2 } & $\mathrm{T} 2$ & -627 & 123 & $1133^{* *}$ & -273 & 1018 & $1685^{* *}$ \\
\hline & $\mathrm{T} 3$ & 114 & 383 & 606 & -434 & 875 & 577 \\
\hline & $\mathrm{T} 4$ & 320 & $1363^{* *}$ & $880 *$ & 1256 & $1333 *$ & $2174^{* *}$ \\
\hline & $\mathrm{T} 5$ & $1372 * *$ & $2446^{* *}$ & $1673^{* *}$ & $2269 * *$ & $2010 * *$ & 3721 ** \\
\hline \multirow{4}{*}{ E3 } & $\mathrm{T} 2$ & -262 & $-733^{* *}$ & 214 & -145 & 258 & 12 \\
\hline & $\mathrm{T} 3$ & -121 & -199 & -282 & 293 & -82 & -662 \\
\hline & $\mathrm{T} 4$ & -455 & -173 & 1123 & -496 & 9 & -79 \\
\hline & $\mathrm{T} 5$ & 522 & $592 * *$ & 789 & 665 & 80 & 109 \\
\hline \multirow{4}{*}{ E4 } & $\mathrm{T} 2$ & $1248^{* *}$ & $1016^{*}$ & $-657 *$ & -209 & $-1491^{* *}$ & -485 \\
\hline & $\mathrm{T} 3$ & $757 *$ & $938 *$ & 249 & -760 & $-769 *$ & -948 \\
\hline & $\mathrm{T} 4$ & $918^{* *}$ & 1221 ** & 511 & $-1776^{* *}$ & $-782 *$ & -956 \\
\hline & $\mathrm{T} 5$ & $971^{* *}$ & 787 & 213 & -394 & -578 & -17 \\
\hline
\end{tabular}

G: Genotype (G1-, G2-, G3-), E: Year-location interaction (E1-ZemunPolje 2016, E2-Parage 2016, E3ZemunPolje 2017, E4-Parage 2017), D: Density (D1-50,000 plants/ha, D2—65,000 plants/ha), Tm: Treatment of defoliation (T1-control, detasseling, T2 - detasseling + 1 leaf, T3-detasseling + 2 leaves, T4-detasseling + 3 leaves, T5-detasseling + 4 leaves); T1-Tm-the differences between the mean values of the factors; * The mean difference is significant at the 0.05 level, ${ }^{* *}$ The mean difference is significant at the 0.01 level.

G1 in E4 for D1 had very significant losses in all defoliation treatments including the largest ones $(1248 \mathrm{~kg})$ at the weakest defoliation intensity (T2). G3 under the same ecological conditions (E4) and the same density (D1) had no losses in any treatment, and in $\mathrm{T} 2$ there was a significant increase in the yield by $1491 \mathrm{~kg} / \mathrm{ha}$.

Interestingly, T4 and T5, very significantly reduced the yield in relation to T1, but did not express significance in the yield reduction in 14 and 13 out of 24 interactions, respectively. 
Numerous patterns of these most complex interactions represent a chance for seed producers to reduce yield losses due to defoliation. At that, one should be very careful, because the selection of the appropriate combinations of factors for the most intensive safe level of defoliation has to be such as to provide high crop yields. G3E1D2 in T5 and G2E2D2 in T4 are the examples for such interactions for safe defoliation.

\subsection{Effects of Defoliation on Morphological and Physiological Traits of Ears and Kernels}

The maize yield depends on the morphological properties of kernels and ears, as well as on their stability and the relationship with environmental conditions $[43,44]$. The kernel row number, kernel number per row and the ear length are some of properties of yield components, the variability of which leads to a decrease or increase in total and kernel weight $[45,46]$. The results show that when these traits were expressed, different interactions occurred to different extents due to actions of factors (Table S5). The actions of genotypes, ecological factors, treatments and their interactions significantly affected variations in KNR and EL. With regard to the increase of quantitative values of KNR and $\mathrm{EL}$, the variation in all GT combinations under the effects of E1 and E2 was significant. KNR and EL gradually increased from G1 to G3. This linearity repeated up to the T4 treatment. The application of the T5 treatment changed effects of factors, first of all, ecological impacts (E), and therewith the direction of changes of means (Figure 2). The climate changes are most noticeable in temperature oscillations, which lead to the change in the duration of the growing season, which greatly affects the environment, genetic and physiological processes and the limitation of effects of yield components [47].

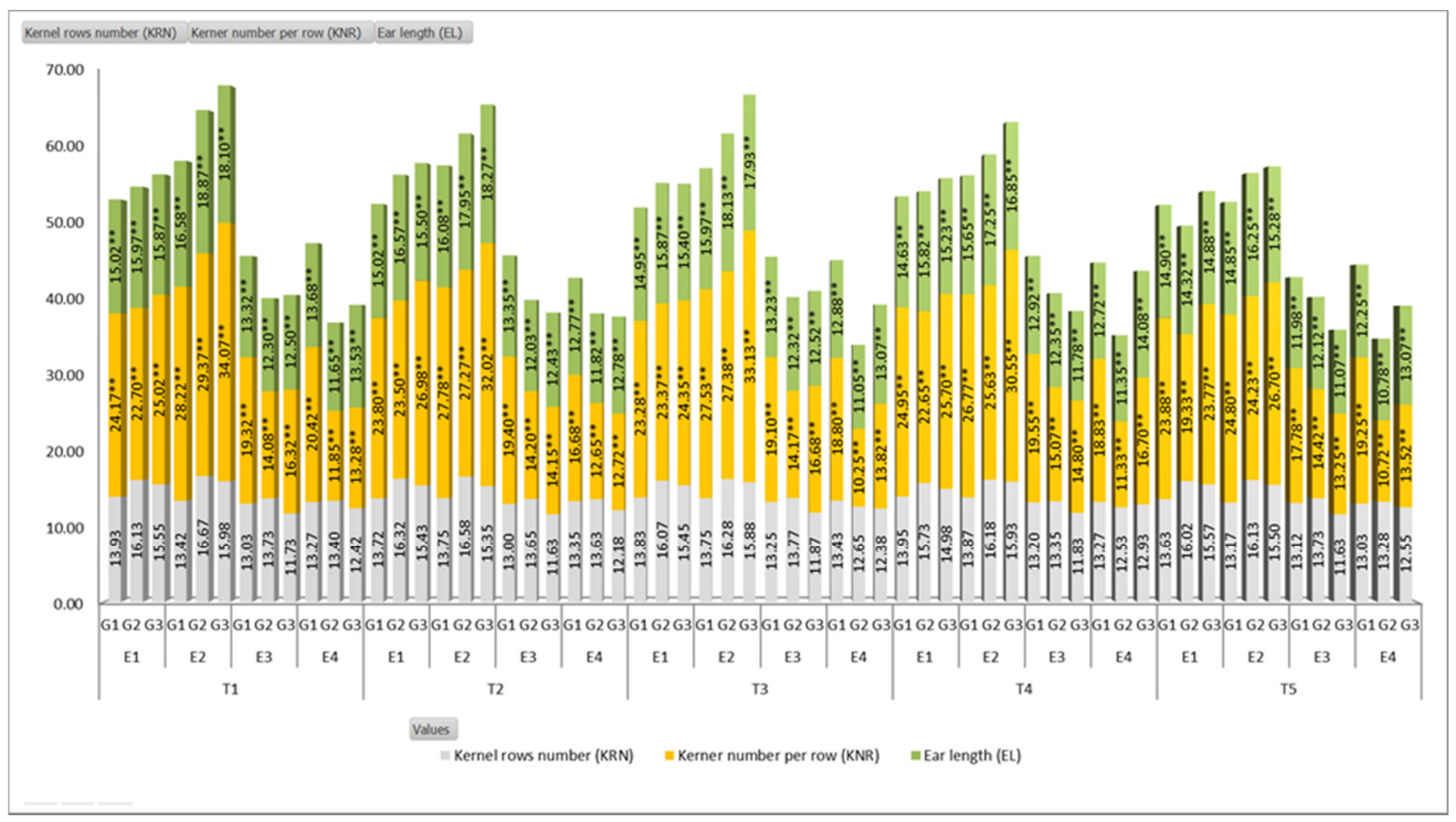

Figure 2. Effects of genotypes (G), Year-location interaction (E) and defoliation (T) on the kernel row number (KRN), number of kernels per row (KNR), the ear length and variability of means by the application of ANOVA. ** Significant at the 0.01 level; * significant at the 0.05 level, without asterisks-not significant.

The 1000-kernel weight under the effects of genotypes, ecological conditions and defoliation treatments did not vary significantly. The largest kernel weight was obtained in the combination of G2E3 factors in the defoliation variants of T1, T3 and T4 (Figure 3). Studies indicate that 1000-kernel weight is more stable across environment and different levels of plant competition than other yield components [48]. 


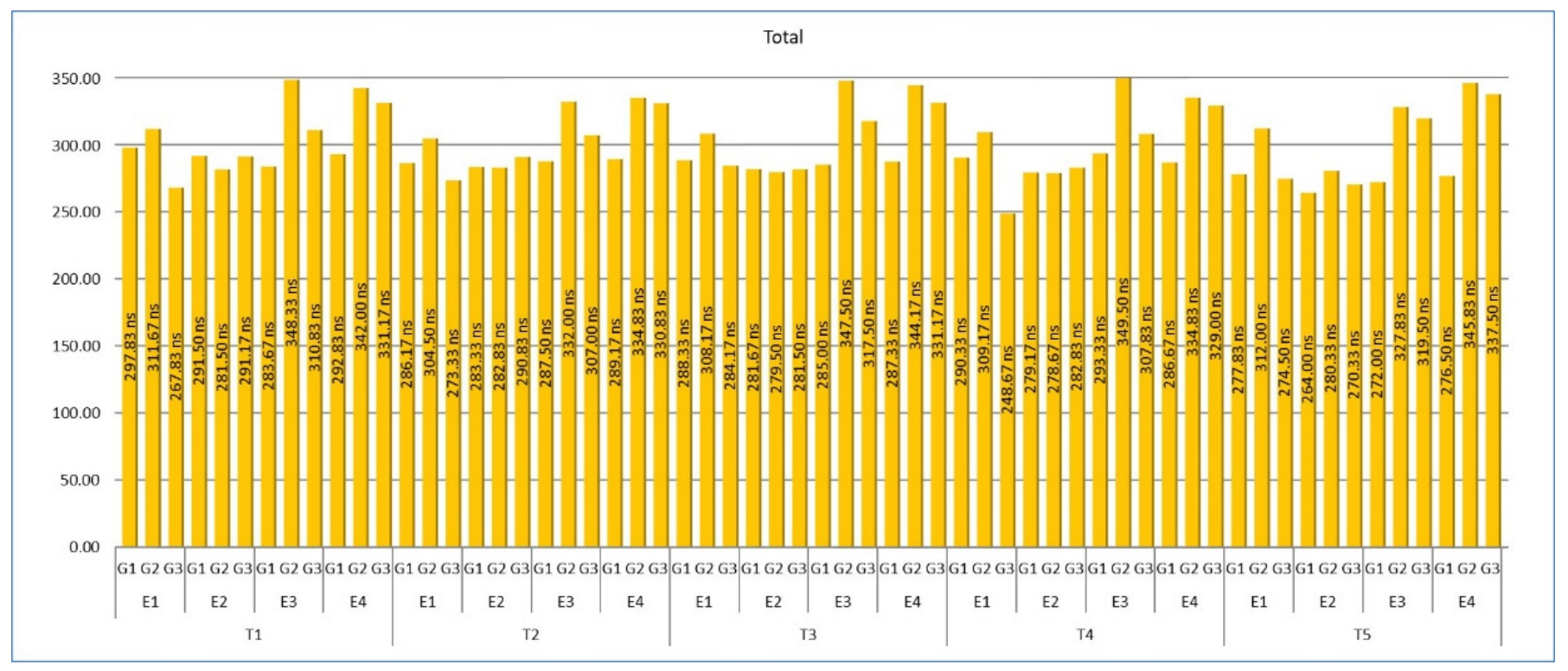

Figure 3. Effects of genotypes (G), Year-location interaction (E) and defoliation (T) on 1000-kernel weight (KW), seed germination (GR) and variations in means by the application of ANOVA, ns-non significant.

Two most important factors affecting the variability of morphological traits and grain yield were singled out by the factorial analysis. The PCA analysis shows that two components represented $88.84 \%$ of the variation obtained (Figure $4 \mathrm{a}$ ). According to the distribution of means, two groups of properties were differentiated: KNR, KRN EL and GY on one hand and KW on the other. As much as $75.33 \%$ of variability of morphological traits was influenced by the applied T1, T2, T3 and T4 defoliation treatments. By observing the distribution of regression factor score values (Figure $4 \mathrm{~b}$ ) of the research variant of defoliation, it was determined that most of the coefficients were located on the right side of the diagram as well as the component matrix of morphological properties (Figure $4 \mathrm{~b}$ ). It can be concluded that the first component was a set of cropping practices that determined the formation of morphological properties and yield. The second factor affected KW with $14.51 \%$ and high negative regression score values. The significant loss of KW occurred when four leaves (T5) were removed in the process of defoliation.

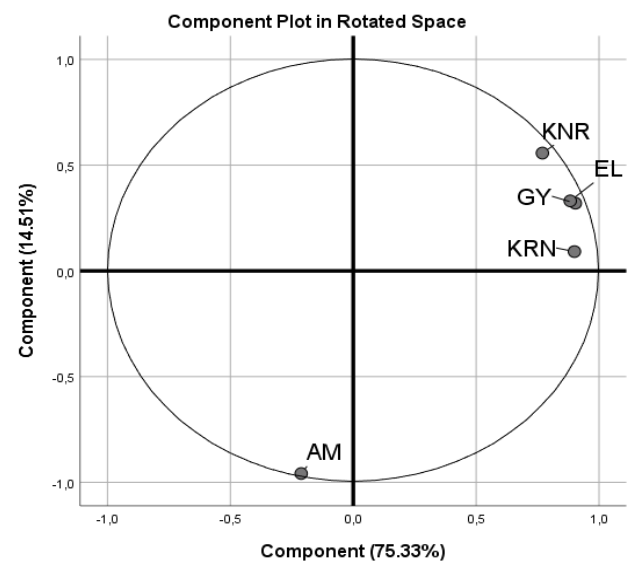

(a)

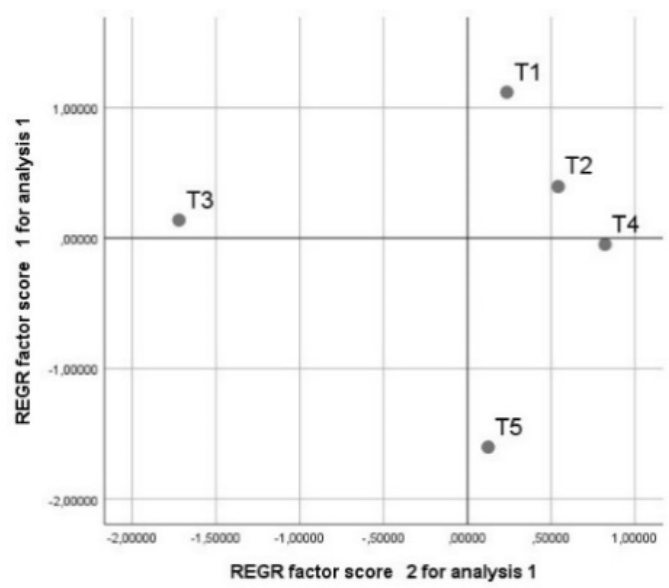

(b)

Figure 4. (a) Plot of principal component analysis of the variables in the study concerning the effects of the detasseling and kernel properties (KRN, KNR, El, KW) and grain yield (GY). KRN-kernel row number, KNR—kernel number per row, EL-ear length, KW-1000-kernel weight; (b) regression factor score of principal comment analysis of the detasseling and kernel properties (KRN, KNR, El, KW). 


\section{Conclusions}

The genotype, the year-location interaction and the crop density expressed characteristic direct effects and a wide spectrum of joint effects on the grain yield loss of maize inbred lines in different defoliation treatments. The genotype productivity was not related to yield losses during defoliation. It is more likely that the level of losses was predominantly affected by the architecture and morphological traits of genotypes, physiological processes, etc. Environmental conditions, especially those related to rainfall, were more unfavorable for the maize production in 2017 than in 2016, which resulted in significantly lower yields obtained in E3 and E4 than in E1 and E2. The rank of genotypes by yields (G2-5549.4 kg/ha, G1-5186.3 kg/ha and G3-4791.3 kg) deviated, to some extent, from the rank of genotypes by yield stability, based on values of their coefficients of variation (G1-33.07\%, G2-47.80\% and G3-71.48\%). The increase of the defoliation intensity was less reflected upon the reduction of grain yields in absolute values $(\mathrm{kg} / \mathrm{ha})$ under unfavorable than under more favorable environmental conditions, which is logical, considering that grain yields under these conditions were lower. The higher the crop density was, the lower the yield losses during defoliation were, whereby it is important that higher seed yields can be obtained at higher densities. The joint effects of observed factors pointed out to numerous possibilities to reduce yield losses during defoliation. From the practical point of view, only those joint effects of the genotype, the year-location interaction and the crop densities that simultaneously provide high crop yields are important for the reduction of losses due to defoliation. Based on obtained results, the highest yields at very intensive but safe levels of defoliation (T5 and T4) were achieved under favorable conditions in terms of sufficient water supply of plants (2016) and in higher sowing density (65,000 pants ha $\left.{ }^{-1}\right)$ for the genotype G3 on degraded chernozem (location of Zemun Polje), and for the genotype G2 on calcareous chernozem (location of Parage). The loss of the leaf area to a certain critical point favored the formation of the kernel row number, number of kernels per row, as well as 1000-kernel weight, after which all the traits were decreased. In the physiological process of germ maturation, the leaf area did not significantly affect quality up to the point of overcoming the "safe" removal of leaves, which was more than four leaves in these trails.

Supplementary Materials: The following are available online at https://www.mdpi.com/article/ 10.3390/agriculture11060509/s1, Table S1: Effect of genotype on differences grain yield between treatments of defoliation, Table S2: Effect of year on differences grain yield between treatments of defoliation, Table S3: Effect of location on differences grain yield between treatments of defoliation, Table S4: Effect of density on differences grain yield between treatments of defoliation, Table S5: Effect of treatments of defoliation on differences physical propertis of maize hybrid seed.

Author Contributions: Conceptualization, S.P., J.B. and G.T.; methodology, J.B.; software, M.T.; validation, D.R., N.D. and G.T.; formal analysis, S.P., M.T.; investigation, D.R.; resources, G.T., N.D.; data curation, D.R., G.T.; writing — original draft preparation, M.T.; writing—review and editing, S.P., J.B.; visualization, M.T., D.R.; supervision, S.P., J.B., N.D.; project administration, G.T., N.D.; funding acquisition, D.R. All authors have read and agreed to the published version of the manuscript.

Funding: This research was funded by Ministry of Education, Science and Technological Development, Republic of Serbia, Grant no. 451-03-68/2020-14/200040 (Maize Research Institute, Zemun Polje, Belgrade-Zemun).

Institutional Review Board Statement: Not applicable.

Informed Consent Statement: Not applicable.

Data Availability Statement: Data sharing not applicable.

Acknowledgments: The authors thank the Ministry of Education, Science and Technological Development, Republic of Serbia, for the financial support.

Conflicts of Interest: The authors declare no conflict of interest. 


\section{References}

1. Costa, L.; Carvalho, I.; Ferreira, L.; Szareski, V.; Pimentel, J.; Troyjack, C.; Barbosa, M.; Da Silva, J.; Conte, G.; Villela, F. The effects of different mechanical detasseling methods on hybrid maize seed production. Genet. Mol. Res. 2019, 18, 18207. [CrossRef]

2. De Pelegrin, J.; Szareski, J.; Demari, H. Yield components of hybrid based on the plant population and artificial defoliation. Aust. J. Basic Appl. Sci. 2016, 10, 136-142.

3. Baretta, D.; Nardino, M.; Carvalho, I.; de Pelegrin, A.; Ferrari, M.; Szareski, V.; Barros, W.; de Souza, V.; de Oliveira, A.; da Maia, L. Estimates of genetic parameters and genotypic values prediction in maize landrace populations by REML/BLUP procedure. Gen Mol. Res. 2017, 16, 16029715. [CrossRef] [PubMed]

4. Nardino, M.; Baretta, D.; Carvalho, I.R.; Olivoto, T.; Follmann, D.N.; Pelegrin, A.; Szareski, V.J.; Lautenchleger, F.; Rosa, T.; Barbosa, M.H. Environment Stratification in the Evaluation of Corn Hybrids in Southern Brazil. J. Agric. Sci. 2018, 10, 333-342. [CrossRef]

5. Ghețe, A.B.; Haș, V.; Vidican, R.; Copândean, A.; Ranta, O.; Moldovan, C.M.; Crișan, I.; Duda, M.M. Influence of detasseling methods on seed yield of some parent inbred lines of turda maize hybrids. Agronomy 2020, 10, 729. [CrossRef]

6. Heidari, H. Effect of defoliation and $\frac{1}{2}$ ear removal treatments on maize seed yield and seed germination. Biharean Biol. 2015, 11, $102-105$.

7. de Toledo Alvim, K.R.; de Brito, C.H.; Brandão, A.M.; Gomes, L.S.; Lopes, M.T.G. Quantificação da área foliar e efeito da desfolha em componentes de produção de milho. Cienc. Rural 2010, 40, 1017-1022. [CrossRef]

8. Sarca, T.R. Chapter, X. Maize; Romanian Academy: Bucharest, Romania, 2004; pp. 345-450.

9. Raza, M.A.; Feng, L.Y.; van der Werf, W.; Iqbal, N.; Khan, I.; Hassan, M.J.; Ansar, M.; Chen, Y.K.; Xi, Z.J.; Shi, J.Y. Optimum leaf defoliation: A new agronomic approach for increasing nutrient uptake and land equivalent ratio of maize soybean relay intercropping system. Field Crops Res. 2019, 244, 107647. [CrossRef]

10. Modarres, A.; Hamilton, R.; Dwyer, L.; Stewart, D.; Dijak, M.; Smith, D. Leafy reduced-stature maize for short-season environments: Yield and yield components of inbred lines. Euphytica 1997, 97, 129-138. [CrossRef]

11. Magalhães, P.C.; Durães, F.O.M.; Oliveira, A.C.d.; Gama, E.E.G. Efeitos de diferentes técnicas de despendoamento na produção de milho. Sci. Agric. 1999, 56, 77-82. [CrossRef]

12. Komatuda, A.S.; Dos Santos, C.M.; De Santana, D.G.; De Souza, M.A.; De Brito, C.H. Influência de métodos de despendoamento na produtividade e na qualidade das sementes de milho. Rev. Bras. Milho Sorgo 2006, 5, 359-368. [CrossRef]

13. Moreira, J.N.; Silva, P.S.L.; Silva, K.; Dombroski, J.L.; Castro, R.S. Effect of detasseling on baby corn, green ear and grain yield of two maize hybrids. Hortic. Bras. 2010, 28, 406-411. [CrossRef]

14. Carvalho, I.; Nardino, M.; Pelegrin, A.; Ferrari, M.; Demari, G.; Szareski, V.; Souza, V. Path analysis and Annicchiarico method applied in relation to protein in corn grains. Aust. J. Basic Appl. Sci. 2016, 10, 300-306.

15. Safari, A.R.; Roshan, N.M.; Barimavandi, A.R.; Amiri, I. Effect of defoliation and late-season stress on yield, yield components and dry matter partitioning of grain corn in Kermanshah region, Iran. Adv. Environ. Biol. 2013, 7, 47-55.

16. Vasilas, B.; Seif, R. Pre-Anthesis Defoliation Effects on Six Corn Inbreds 1. Agron. J. 1985, 77, 831-835. [CrossRef]

17. Frascaroli, E.; Casarini, E.; Conti, S. Response of maize inbred lines to a defoliation treatment inducing tolerance to cold at germination. Euphytica 2005, 145, 295-303. [CrossRef]

18. Cumagun, C.J.R.; Manalo, J.O.; Salcedo-Bacalangco, N.A.; Ilag, L.L. Cellulose decomposing ability of Trichoderma in relation to their saprophytic survival. Arch. Phytopathol. Plant Protect. 2009, 42, 698-704. [CrossRef]

19. Sheridan, J.C. SPSS: Analysis without Anguish: Version 12.0 for Windows; John Wiley \& Sons: Hoboken, NJ, USA, 2005.

20. Fox, T.; DeBruin, J.; Haug Collet, K.; Trimnell, M.; Clapp, J.; Leonard, A.; Li, B.; Scolaro, E.; Collinson, S.; Glassman, K. A single point mutation in Ms44 results in dominant male sterility and improves nitrogen use efficiency in maize. Plant Biotechnol. J. 2017, 15, 942-952. [CrossRef] [PubMed]

21. García-Martínez, H.; Flores-Magdaleno, H.; Ascencio-Hernández, R.; Khalil-Gardezi, A.; Tijerina-Chávez, L.; Mancilla-Villa, O.R.; Vázquez-Peña, M.A. Corn Grain Yield Estimation from Vegetation Indices, Canopy Cover, Plant Density, and a Neural Network Using Multispectral and RGB Images Acquired with Unmanned Aerial Vehicles. Agriculture 2020, 10, 277. [CrossRef]

22. Golba, J.; Studnicki, M.; Gozdowski, D.; Mądry, W.; Rozbicki, J. Influence of genotype, crop management, and environment on winter wheat grain yield determination based on components of yield. Crop Sci. 2018, 58, 660-669. [CrossRef]

23. Mądry, W.; Rozbicki, J.; Gozdowski, G.; Golba, J.; Piechociñski, M.; Studnicki, M.; Wery, J.; Shili-Touzi, I.; Perrin, A. Typology of grain yield formation patterns by yield components in winter wheat cultivars grown across Polish environments. In Proceedings of the AGRO 2010, the XI ESA Congress, Montpeilier, France, 29 August-3 September 2010; European Society for Agronomy (ESA): Conthey, Switzerland, 2010; pp. 601-602.

24. Slafer, G.A.; Savin, R.; Sadras, V.O. Coarse and fine regulation of wheat yield components in response to genotype and environment. Field Crop. Res. 2014, 157, 71-83. [CrossRef]

25. Irfanullah, H.A.; Hussain, A.A.I.; Khan, M.W.; Ahmadzai, M.D. Yield and yield attributes of maize (Zea mays L.) as affected by detasseling and potassium fertilization. Pure Appl. Biol. (PAB) 2017, 6, 958-964.

26. Gao, Z.; Sun, L.; Ren, J.-H.; Liang, X.-G.; Shen, S.; Lin, S.; Zhao, X.; Chen, X.-M.; Wu, G.; Zhou, S.-L. Detasseling increases kernel number in maize under shade stress. Agric. For. Meteorol. 2020, 280, 107811. [CrossRef]

27. Uribelarrea, M.; Cárcova, J.; Borrás, L.; Otegui, M.E. Enhanced kernel set promoted by synchronous pollination determines a tradeoff between kernel number and kernel weight in temperate maize hybrids. Field Crop. Res. 2008, 105, 172-181. [CrossRef] 
28. Zhou, B.; Yue, Y.; Sun, X.; Ding, Z.; Ma, W.; Zhao, M. Maize kernel weight responses to sowing date-associated variation in weather conditions. Crop J. 2017, 5, 43-51. [CrossRef]

29. Mi, N.; Cai, F.; Zhang, Y.; Ji, R.; Zhang, S.; Wang, Y. Differential responses of maize yield to drought at vegetative and reproductive stages. Plant Soil Environ. 2018, 64, 260-267.

30. Mafouasson, H.N.A.; Gracen, V.; Yeboah, M.A.; Ntsomboh-Ntsefong, G.; Tandzi, L.N.; Mutengwa, C.S. Genotype-by-environment interaction and yield stability of maize single cross hybrids developed from tropical inbred lines. Agronomy 2018, 8, 62. [CrossRef]

31. Khaki, S.; Wang, L.; Archontoulis, S.V. A cnn-rnn framework for crop yield prediction. Front. Plant Sci. 2020, 10, 1750. [CrossRef] [PubMed]

32. Reeves, G.W.; Cox, W.J. Inconsistent responses of corn to seeding rates in field-scale studies. Agron. J. 2013, 105, 693-704 [CrossRef]

33. Edwards, J.W. Genotype $\times$ environment interaction for plant density response in maize (Zea mays L.). Crop Sci. 2016, 56, 1493-1505. [CrossRef]

34. Xu, W.; Liu, C.; Wang, K.; Xie, R.; Ming, B.; Wang, Y.; Zhang, G.; Liu, G.; Zhao, R.; Fan, P. Adjusting maize plant density to different climatic conditions across a large longitudinal distance in China. Field Crop. Res. 2017, 212, 126-134. [CrossRef]

35. Hmielowski, T. Maize yield potential. CSA News 2018, 63, 8-9. [CrossRef]

36. Falihzade, F.; Mojadam, M.; Lack, S. The effect of source-sink restriction and plant density changes on the role of assimilate remobilization in corn grain yield. Int. J. Agric. Res. 2013, 5, 2459-2465.

37. Li, R.; Liu, P.; Dong, S.; Zhang, J.; Zhao, B. Increased maize plant population induced leaf senescence, suppressed root growth, nitrogen uptake, and grain yield. Agron. J. 2019, 111, 1581-1591. [CrossRef]

38. Cao, Y.J.; Wang, L.C.; Gu, W.R.; Wang, Y.J.; Zhang, J.H. Increasing photosynthetic performance and post-silking N uptake by moderate decreasing leaf source of maize under high planting density. J. Integr. Agric. 2021, 20, 494-510. [CrossRef]

39. Da Silva, S.; Pereira, L.; Sbrissia, A.; Hernandez-Garay, A. Carbon and nitrogen reserves in marandu palisade grass subjected to intensities of continuous stocking management. J. Agric. Sci. 2015, 153, 1449. [CrossRef]

40. Bonser, S.P.; Aarssen, L.W. Interpreting reproductive allometry: Individual strategies of allocation explain size-dependent reproduction in plant populations. Perspect. Plant Ecol. Evol. Syst. 2009, 11, 31-40. [CrossRef]

41. Ona, A.D.; Muntean, L.; Haș, V.V.; Varga, A. Combining ability for yield of single-cross hybrids derived from maize composites (Zea mays L.). Not. Bot. Horti Agrobot. Cluj Napoca 2019, 47, 465-469. [CrossRef]

42. Tokatlidis, I.S. Adapting Maize Crop to Diverse Agro-Ecosystems. In Sustainable Agriculture Reviews; Springer: Berlin/Heidelberg, Germany, 2013; pp. 97-117.

43. Novacek, M.; Mason, S.; Galusha, T.; Yaseen, M. Twin rows minimally impact irrigated maize yield, morphology, and lodging. Agron. J. 2013, 105, 268-276. [CrossRef]

44. Testa, G.; Reyneri, A.; Blandino, M. Maize grain yield enhancement through high plant density cultivation with different inter-row and intra-row spacings. Eur. J. Agron. 2016, 72, 28-37. [CrossRef]

45. Assefa, Y.; Vara Prasad, P.; Carter, P.; Hinds, M.; Bhalla, G.; Schon, R.; Jeschke, M.; Paszkiewicz, S.; Ciampitti, I.A. Yield responses to planting density for US modern corn hybrids: A synthesis-analysis. Crop Sci. 2016, 56, 2802-2817. [CrossRef]

46. Milander, J.J.; Jukic, Z.; Mason, S.C.; Glausha, T.; Kmail, Z. Plant population influence on maize yield components in Croatia and Nebraska. Crop Sci. 2016, 56, 2742-2750. [CrossRef]

47. Sadras, V.O.; Slafer, G.A. Environmental modulation of yield components in cereals: Heritabilities reveal a hierarchy of phenotypic plasticities. Field Crop. Res. 2012, 127, 215-224. [CrossRef]

48. Eichenberger, S.; Miguez, F.; Edwards, J.; Knapp, A. Changes in kernel filling with selection for grain yield in a maize population. Crop Sci. 2015, 55, 521-526. [CrossRef] 